\title{
Constructing Practical Teaching System of Logistics Management Based on Internet-thinking in Application Colleges and Universities
}

\author{
Shufan Zhu ${ }^{1}$, Rongyan Zhu ${ }^{2}$ \\ ${ }^{1}$ Lecturer, Senior Logistics Division, School of Logistics Management, Wuhan Technology and Business \\ University, No.3, Huangjiahu west road, Wuhan, Hubei, China \\ ${ }^{2}$ Ph.D, Hubei Business Service Development Research Center, Wuhan Technology and Business University, \\ No.3, Huangjiahu west road, Wuhan, Hubei, China \\ zhu_shufan1@163.com,Zhurongyan1985@163.com
}

Keywords: Application Colleges and universities, Internet-thinking, Practical teaching system, CDIO, Multi-evaluation system

\begin{abstract}
According to the demand of application-oriented talents in logistics industry, this paper constructs practical teaching system of logistics management based on Internet-thinking in applied universities. This practical teaching system includes practical teaching content system based on CDIO, which are composed of "course-project-base", practical teaching course system based on target ability system of Internet-thinking, comprehensively practical teaching multi-evaluation system, practical teaching operation management and teaching guarantee system, and so on. In consequence, this paper broadens scope of practical teaching system of logistics management in applied universities, which has more practical guiding significance.
\end{abstract}

\section{INTRODUCTION}

Along with higher education entering into the phase of connotative development in our country, more and more colleges and universities focus positioning of talent training reform on demand of industrial development. Last few years, a large number of areas and schools have carried on a series of research from varying degrees such as talent training mode, professional development and practical teaching, which aiming at improving students' professional ability and cultivating applied talents with high quality suitable for production logistics in manufacturing enterprise and service quality in logistics enterprise. The most important way of cultivating students' professional ability is to strengthen practical teaching except theoretical teaching training. In recent years, practical teaching of applied colleges has obtained some achievements, and students' practical ability also has improved greatly, however, there is a certain gap between enterprise actual demand and talents cultivation target, including lack of systematic arrangement of practical curriculum, lack of practical fields and facilities, lack of practical teaching experience for teachers, which lead to quality of practice teaching to be further improved. Therefore, how to grasp real-time requirement of logistics industry in Applied colleges and combine with subject characteristics, then, construct practical teaching system to improve students' professional ability and advantage of employment competition, finally, explore sustainable development of higher quality application talents has become the top priority in application colleges and universities (He et al., 2016).

\section{DEMAND ANALYSIS OF STUDENTS' PROFESSIONAL ABILITY FOR LOGISTICS MANAGEMENT IN APPLIED UNIVERSITIES}

Demand analysis of professional ability Targets to these students of logistics management for objects who work in production logistics in line with manufacturing enterprise and service logistics for logistics enterprise, mainly including four levels, such as basic ability, professional ability, occupation ability and key ability. Basic skills are basic operational skills in logistics work. Professional competence is professional ability and knowledge required for a certain specific job, by which students can complete technical work independently and fulfil post responsibilities with strong sense of accountability. Occupation ability is the ability and knowledge of cross-specialty and interposition basing on basic ability and professional competence, which is sustainable development ability. people are high level persons in the whole project team, who have clear analysis thought of whole project operation and organization in this level. Then, people at this level can lead a project team and make effective planning schemes in order to motivate team members to work effectively. Key ability is to improve core competitive ability. When environment or jobs have changed, people can rapidly adapt environment and acquire new skills and knowledge, which have systematic learning ability, suitable ability, clear role definition and organization innovation ability, and so on.

Key ability is to emphasize cultivation of learning ability, not limited to a specific professional knowledge and ability, but including ability of team organization and team coordination, planning ability, design ability and innovation ability, etc. These abilities can be 
cultivated more effectively in practical environment so that scene practical teaching construction should be paid more attention in the process of students' vocational ability training. Theoretical courses are mainly taught by teachers and students are mostly stay in the stage of "understanding-memory" Shallow learning and passive learning, which lack problem analysis and thinking ability. Practice teaching mainly takes initiative to search learning and grasp knowledge in interactive course or activity by taking actions with brains, doing in the process of learning and learning in the process of doing, which develop students' practical ability, team cooperation ability, strain ability, analytical ability and life-long learning ability (Wang, 2015).

\section{PROBLEMS AND REASON ANALYSISES OF PRACTICAL TEACHING FOR LOGISTICS MANAGEMENT MAJOR IN APPLIED UNIVERSITIES}

\subsection{Problems}

Practical teaching system construction has not yet been effectively combined with professional capacity demand analysis. The main problems include following several aspects (Y. H. Wang et al., 2016):

There is relatively little proportion of experimental training and internship, for which existing practical teaching system account for only about a third of total teaching hours. Practical curriculums are commonly set by course teachers, which have not been effectively combined with enterprise actual project. Consequently, these students have not been effectively trained with their practical ability.

Practical teaching content is lack of pertinence. Currently practical courses are composed of course experiment, practical teaching, off-campus internship and graduation design in personnel training plan scheduling. Instructors usually assign experimental contents in accordance with course arrangement and students submit corresponding documents, which is at a lower level. Practical teaching in school is deepening of curriculum experiment, absent of comprehensive practical training and systematic training program. What's more, practical training outside school is mainly students' replacement internship and rotation internship in practical teaching bases without pertinent training and cultivation. Therefore, applied colleges and universities should give priority to practical teaching, of which content should be designed according to enterprise actual work process and post needs, focusing on cultivating students' ability of project management team.

Practical teaching quality evaluation is lack of effective evaluation. Existing practical teaching quality evaluation may be arbitrary and score evaluation methods mainly include students' attendance and internship report, lacking of process evaluation to some extent. Meanwhile, practical training class has not yet established effective standard and management system, leading to limited communication for different training lessons and less Systematic for practical courses.

\subsection{Reason Analysis}

\subsubsection{Pay Little Attention to Practical Teaching}

Existing manpower resources of practical teaching is relatively rare, leading to systematic teaching system of related software operating not being formed in campus training rooms.

\subsubsection{Lack of Practical Teaching Experience}

Existing practical guidance teachers have rich theoretical knowledge, but not engaged in relevant work. Therefore, it is difficult for teachers to effectively guide students' practice teaching.

\subsubsection{Lack of Effective Supervision Management Mechanism and Incentive Mechanism}

Practical teaching quality assurance needs teachers spend more time and energy. However, current incentive mechanism for practical teaching is not yet perfect. Meanwhile, current ways incline to theoretical teaching which not guarantee effectiveness of practical teaching.

\section{DEFINITION AND PRINCIPLES OF PRACTICAL TEACHING SYSTEM IN LOGISTICS MANAGEMENT PROFESSIONAL BASED ON INTERNET THINKING}

\subsection{Definition of Practice Teaching System in Logistics Management Professional Based on Internet Thinking}

Internet of mesh structure has no central node without absolute core point, in the consequence, Internet business model is decentralization to realize distributed. Equality and open is indeed core of Internet. At the age of Internet Mesh society, model social value is attributed to breadth and thickness of jointly point related to individual, that is, size of individual resources and information content. Therefore, individuals need to indicate equal and open in the network society with the purpose of linking more resources and information. After that, thinking way of individual and corporation gradually consider from Internet perspective.

Based on individual value characteristics and Internet thinking changing operation of traditional logistics industry, practical teaching system construction aim networking, sharing, win-win for goal, which transfer existing practical teaching system, promote talents of logistics management professional to adapt society quickly and improve their core competitiveness faster.

\subsection{Principle of Practice Teaching System in Logistics Management Professional Based on Internet Thinking}

\subsubsection{Crossover Thinking}

With the emergence of new technology such as Mobile Internet and Internet of things, Internet-crossover transfer from internet into traditional off-line field and integration scope of traditional industry and information technology further expand. With industry boundary narrow, integration process of Internet-financial, Internet-TV, Internet-education and Internet-medical 
constantly accelerate, which break through closely guarded border of traditional industry from different aspects, such as product morphology, service way and profit model. With the help of Internet, enterprise can realize cross-border integration and help generalizing yourself with outside resources to complete resources integration. Therefore, it is very important that students should be guided to take advantage of other students to form a team and implement cross-border cooperation.

\subsubsection{User Thinking}

User thinking refers to each node of value chain taking customer as core centre involved in enterprise operation process. Customers include internal customers and external customers. Internal customers refer to corresponding requirements of next node, especially in logistics industry. Logistics belong to service industry, which need pay more attention to customer satisfaction. Therefore, teachers should guide students to be good at understanding user requirements of next link in the process of practical teaching when working in logistics jobs. Meanwhile, it is necessary for students to learn to analysis user requirements to meet user needs with effective way (Cai, 2015).

\subsubsection{Fans Thinking}

Fans are special groups of users, maybe potential buyers, also maybe the most loyal buyers. Logistics industry can make their own users obtain extreme experience, which infect consumers, as far as possible to improve their core user activity. While the number is to be a certain extent, fans can help to build effective marketing system. In future, enterprise is difficult to survive without fans. Accordingly, talent training mode of logistics professional focus on cultivating students' ability, such as Internet-logistics operations and promotion, Internet-logistics information system planning and construction, Internet-logistics information data acquisition and mining based on Internet-thinking. These jobs are not only unilaterally things which logistics enterprise should be involved in, but also inclining to admitting customers participating in product design to improve customer's loyalty, thus enhance conversion rate of customers transferring into fans.

\section{CONSRUCTING PRACTICAL TEACHING SYSTEM OF LOGISTICS MANAGEMENT BASED ON INTERNET THINKING}

\subsection{Clarify Practical Teaching Goal System}

Starting from applied talents training target, it is essential to understand current enterprise demand for students' practical ability with deep investigation and analysis to cooperative logistics enterprises, then communicate with experienced experts and senior staff to jointly make practical teaching target of logistics management major. After that, Internet-thinking practical teaching system can be built, including ability quality elements based on CDIO, such as basic ability, professional ability, post ability, key ability, internetpractical ability and comprehensive integration ability.

CDIO is a closed loop mode being dominated by “conception-design-implementation-operation”, which provide engineering education and systemic study background for students in process of actual system operation and conceptual design of product. This way exercise students' ability of systemic thinking, systemic construction and maintenance, which keep consistent with personnel training goals of logistics management professional education.

\subsection{Build a Practical Teaching Content System Based on CDIO “Curriculum- Project-Base”}

According to core concept of practical teaching goal system, practical teaching content systems are based on Internet-thinking guiding principle and specify content of practical teaching target. This way cultivates students' practical application ability and system thinking ability, then, divide practical teaching content system according to ability module which is based on CDIO "projectcourse-base”, as shown in figure 1.

CDIO (engineering education) run along a complete chain with conception, design, production engineering or construction and operation, embracing professional teaching ideas to carry out a series of practical activities with the help of design project, including cognition practice, production practice, graduation practice, individual course design project, curriculum group of practical project design, graduation comprehensive design (Wang et al., 2015). In the first, this system can start from engineering introduction and cognitive activity and conceive practical curriculum system, including four layers, such as base layer, professional layer, Internetpractical layer and comprehensive layer. Meanwhile, this mode can design practical activity from freshman to senior year and coherent integration of four years with the help of existing intelligent practical teaching environment and course management software. At the same time, this method will expand extracurricular practical activities, including factory visits, tutors' research projects, various disciplines competitions, entrepreneurship practices and undergraduate research training programs.

Experiment practical teaching adhere to syllabus needs of practical courses, relying on intelligent digital teaching resources and cloud platform to establish practical curriculum standards and evaluation, practical teaching system curriculum system and practical teaching staff. What's more, this teaching method adopt a series of studying methods to start small project-class study, such as induction and deduction method, online education, traditional education, self-study, studyleading, small class teaching, grouping study, competition learning methods, real-task project orientation based on actual situation. Therefore, it is purpose that is to aim at cultivating students' team cooperation ability and improving ability of autonomous learning, collaborative learning and inquiry learning. 


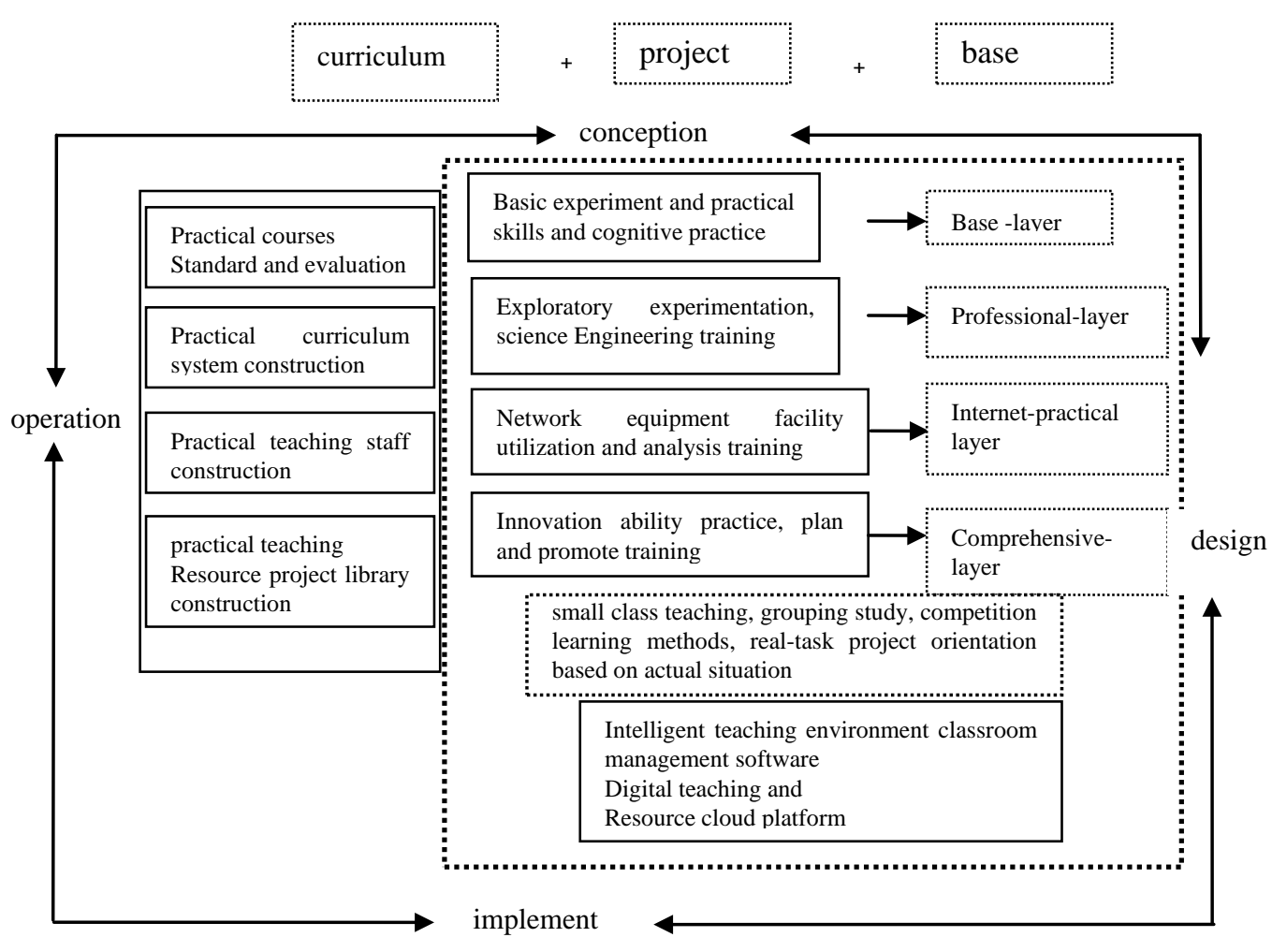

Figure1: practical teaching content system based on CDIO “curriculum- project-base”

\subsubsection{Base-layer Practical Module}

Basic practical module is mainly practical course in which certain chapters of theoretical courses set up, corresponding to fairly practical courses. This module admits students to further understand chapter contents

by practice and improve students' operation ability quickly.

\subsubsection{Professional-layer Practical Module}

Professional-layer practical module are mainly several high-relevance course groups of practical projects, focusing on training students' practical ability in key position, further strengthening professional theory knowledge. At the same time, this module cultivates students' core ability in course groups of practical projects to improve students' communication and coordination ability.

\subsubsection{Internet-practical Module}

Logistics industry belongs to service industry. With rapid development of Internet, teaching should train students to focus on customers' real-time needs and practical operation ability. Meanwhile, teaching should teach students to integrate online and offline, domestic and foreign resources to carry out Internet-logistics information system design and project plan, using Internet-mobile devices and network equipment to mine and collection analysis of logistics data.

\subsubsection{Comprehensive-practical Module}

Comprehensive integration practical module mainly trains students how to design and plan logistics information system based on three levels module, which further cultivate students' internet resource integration, supply chain management of service product promotion.

\subsection{Establish Practical Teaching Curriculum System Based on Internet-thinking Target Capability System}

Constructing practical teaching course system depends on typical cooperation enterprise, transferring real or unsolved problems into course project for practical teaching process. Meanwhile, this way makes full use of existing Internet technology and take the form of mutual transformation of teacher and enterprise mentor to guide the students' practical teaching together. Combining with four levels of practical teaching content system module, each level includes different practical courses according to ability target requirements. Practical courses of basic level include: logistics work rules and regulations, engineering drawing, scheme design, information system development. Major courses of professional level are: third-party logistics, warehousing management, supply chain management, ERP simulation comprehensive training, logistics planning and development. Practical courses of Internet layer mainly include: utilization of Internet- mobile devices, web-based logistics product development design, web-based logistics product planning and promotion, internet-based logistics products brand maintenance. Practical course of comprehensive Layer mainly includes: Internet-based logistics resource integration and data analysis, Internet-based logistics product development and design project, web-based logistics product supply chain management and practices project, cross-major comprehensive practice, graduation thesis (Wang et al., 2016).

Characteristic courses mainly include in this course system:

Logistics product development design based on Internet cooperate with logistics companies on the Internet with actualized method of project management. 
Then, this course is a practical course by which students can develop and design product in terms of optimization and revolution of partial logistics link.

Resources integration and data analysis of logistics products based on internet mainly cooperate with domestic or foreign advanced colleges and logistics enterprise to collect existing advanced technology of logistics product development integrate practical resources.

Supply chain management practice project of logistics products based on internet needs to coordinate with logistics enterprises that are carrying out or will be going to carry out logistics change based on Internet. It is the course that transform

Involved matters into practical project in process of enterprise reform. College and logistics enterprises jointly explore reform direction, taking customer demand as guidance orientation, then, putting forward business restructuring plan from perspective of supply chain.

\subsection{Construct Diversified Practical Teaching Evaluation System}

Diversified practical teaching evaluation systems adopt implement results and implement process to evaluate students' presentation. According to professional ability target, this way concludes concrete combinations of different evaluation ways, such as teacher evaluation, self-evaluation, mutual evaluation and enterprise mentor evaluation.

Practical teaching multi-variate evaluation system adopts several confluent methods of teacher evaluation, self-assessment, mutual evaluation and enterprise tutor evaluation. Teacher evaluation mainly examines whether students can complete corresponding training project report according to practical requirements. Mutual assessment mainly examines students' teamwork ability, which can actively participate in team cooperation projects and propose effective solutions to problems. Evaluation of corporate mentors mainly examines the program effectiveness by student project team. Basic practical curriculum is mainly to practice students' practical operation skills by adopting methods of teacher evaluation, self-assessment and mutual assessment. Professional practice curriculum adopts method of teacher evaluation, self-assessment and mutual assessment. If tasks of Internet practices or comprehensive practices are case analysis, class evaluation can utilize teacher evaluation, self-evaluation and mutual combination, if task type or design type, class evaluation can combine teacher evaluation and enterprise tutors' evaluation.

Formative assessment and summative assessment can be confluently employed in process of evaluation with four different evaluation methods. Formative assessment collects students' phase achievements to acquire their academic progress, assisting teachers and students to monitor teaching process and points out that teaching need to be improved. Summative assessment usually collects all kind of information and check students' all aspects of expected learning effect at the end of teaching activity to enhance comprehensive understanding of learning effect. Therefore, all assessment information collected must be used to improve teaching and learning and improve whole professional plan in general. What' more, evaluation standard or content include students' ability performance of innovation practice, class presentation, extracurricular study and research, the second classroom performance, network autonomous learning performance, designing experimental scheme, writing ability of research overview, communication situation with teachers, group cooperative learning, social practice and so on (Shen, 2016).

\subsection{Construct Practical Teaching Operation Management and Teaching Guarantee System}

Practice teaching operation management and teaching guarantee system is an important factor for normal operation of practice teaching, mainly including following aspects (Liao, 2016):

Set up deep cooperation mechanism to schools and practice teaching base enterprise. Relying on Internet intelligent equipment, colleges can improve and upgrade existing training rooms and practice project, strengthening further cooperation with new logistics enterprise by resource sharing mechanism.

Build system of teachers and enterprise tutor transferring mutually. Teachers can be encouraged to apply for further credential exercise in business and actively participate in relevant software operating training to improve effectiveness of practice course and practical ability, cultivating double teachers to optimize structure of teachers.

Establish an effective supervision management mechanism. There are so many operation management modes being introduced into enterprises, for example, rule regulation and examination system to simulate real scene, admitting students recognize practice normality of psychologically, reducing randomness in the process of training and give full play to students' subjective initiative of participating in training.

Establish an effective incentive mechanism. It is necessary to develop practice teaching expenditure management system and accounting methods of practical teaching workload. What's more, it need pay more attention to motivate teachers who have outstanding performance in process of practical teaching, and fully mobilize teachers' enthusiasm of practical teaching to ensure effective quality of practice teaching.

\section{CONCLUSIONS}

In this paper, a CDIO practical teaching system has been proposed in applied colleges and universities, based on existing problems and reasons analysis of practical teaching. The system design targeted practice teaching course content with intelligent teaching environment, digital teaching resources cloud platform, in view of the base layer, professional practice, Internet layer and comprehensive layer. Finally, practical curriculum standards and evaluation, practical curriculum system construction, construction of practical teaching staff, construction of practical teaching resources project library and other aspects are implemented to ensure operation and realization of practical teaching content 
system.

For future works, we will be focusing on implementation of practical teaching curriculum content, especially characteristics of practical courses. What's more, to ensure smooth implementation of practical teaching content system, practical teaching assurance system should be built from different levels.

\section{REFERENCES}

[1] He, J. F., Ye, Z. X., He, Y. S., Liu, L., Xu, W., 2016. Construction of Innovative talent training in applied undergraduate colleges and universities based on interdisciplinary perspective-taking practice teaching reform of embedded system course as an example, Journal of vocational education BBS. 33, pp.42-44.

[2] Wang, S. L., 2015. Technical skills demand and constraints analysis of vocational logistics information talents in higher vocational education based on "Internet plus" background, Logistics technology. 38 (5), pp.51-53.

[3] Wang, Y. H., Liu, X. G., Chen, Y., 2016. Construct practical teaching system of economical and management professional in local agricultural colleges and universities based on vocational ability training, Occupational technology education. 37 (26), pp.33-36.

[4] Cai, L., 2015. Cultivation mode of Internet thinking type in higher vocational clothing design, Professional education BBS. 14 (36), pp.56-59.

[5] Wang, P. G., Hao, R. M., Zhang, J. S., 2015. Construct and explore "same frequency common vibration" practical teaching system industry-taking costume design and engineering in changshu institute of technology as an example, Journal of vocational education BBS. 36, pp.79-82.

[6] Wang, J. S., Pan, X. T., Zhu, X., 2016. Construct practical teaching system of grading cultivation training in high vocational and applied colleges-taking electronic automation technology as an example, Professional education BBS. 23, pp.48-50.

[7] Shen, H., 2016. Practice teaching mode of "quaternity" hotel service English in higher vocational colleges" based on mobile Internet era, Occupational technology education. 37 (17), pp.35-38.

[8] Liao, Z. R., 2016. Construct professional practice teaching system in higher vocational colleges-taking architecture vocational technical college as an example in Sichuan, Occupational technology education. 37 (26), pp.37-40.

\section{APPENDIX}

Fund Project: University-level Teaching Reform Project "Innovative Logistics Talent Cultivation Model in Applied Universities Based on Internet Era” (no.:2016Y02), host: Shufan Zhu 